\title{
RUMEN CILIATES IN LAMB POSTNATAL ONTOGENESIS
}

\author{
J. CRHA, ${ }^{1}$ J. STR̛̃fŽ, M. SKŘIVÁNEK and Z. VALACH
} Department of Physiology, ${ }^{1}$ Department of Diagnostics, Therapy and Control of Animal Diseases,
University of Veterinary Science, 61242 Brno

Received March 29, 1990

\begin{abstract}
Crha J., J. Stříž, M. Skřivánek, Z. Valach : Rumen Ciliates in Lamb Postnatal Ontogenesis. Acta vet. Brno, 60, 1991: 137-141.

The development of rumen microfauna in 7 Merino lambs from birth to 3 months was investigated. In the first week after birth, the genus Entodinium appeared; in the second week Polyplastron multivesiculatum; in the third week Eremoplastron bovis and Enoploplastron triloricatum; in the 5th week Diploplastron affine and Isotricha prostoma; and in the 8th week Ophryoscolex tricoronatus and Dasytricha ruminantium. The average numbers of ciliates were $7 \times 10^{3} \cdot \mathrm{ml}^{-1}$ in the second and third weeks, $6 \times$ $10^{3} \cdot \mathrm{ml}^{-1}$ in the 4th week, and later they oscillated between $3 \times 10^{3}$ and $1 \times 10^{4} \cdot \mathrm{ml}^{-1} \mathrm{ru}-$ men liquor.
\end{abstract}

Ciliates, rumen, ontogen, sheep

Knowledge of the forestomach microfauna in the young of ruminants is essential for understanding of their preruminant digestion (Oxford 1955; Bryant et al. 1958; Hungate 1966; Fonty et al. 1984). Contact with adults provides the original colonization by microfauna (Fonty et al. 1986). Data on rumen ecology are necessary for efficient use of various feed additives that may cause changes in rumen metabolism and digestion of the organic matter and thus substantially influence performance of the animals.

The aim of the present work is to study the occurrence of the individual ciliate species in the young ruminants and to compare their rumen microfauna with that of the contacted adult individuals.

\section{Materials and Methods}

A group of 7 Merino lambs born within a week in the Cooperative Farm Boritov was used in the study. The animals were examined for 3 months from the first week of life. From birth to 3 weeks of age the lambs were placed in pens with their mothers and were separated from other animals. From week 4 they were placed with other lambs and had contact with their dams during sucking. Until week 9 they were allowed to suck at any day or night time from their mothers placed in a neighbouring pen. From the end of week 9 , they were gradually weaned.

From week 3, the lambs were fed ground meal in the morning, from week 7 they were given granulated alfalfa. From week 8 , they were fed a concentrate mixture for lambs, in the morning and hay with granulated alfalfa in the afternoon, and water. After weaning they were fed concentrate for lambs, hay and water.

Samples of rumen fluid were collected once weekly at the same time of day with a special oesophageal tube and underpressure pump. The collection apparatus was rinsed and disinfected prior to each sampling. The collected rumen fluid was immediately mixed with $10 \%$ formaldehyde. To compare microfauna of mothers and their young, in the second week after delivery, the rumen fluid of the dams was collected, too.

Prior to microscopical examination each formaldehyde-treated sample was shaken, a part of it was placed into a Fuchs-Rosenthal counting chamber and the numbers of ciliates in $1 \mathrm{ml}$ rumen 
fluid were counted. From each rumen fluid sample a sediment portion was employed. Microscopic preparations for species determination were made from a sediment portion of each rumen fluid sample. The nuclei of ciliates were stained with methyl green, acetcarmine and hematoxylin (Heidenhein, Ehrlich, Garazzi), the skeletal plates were visualized by chlorzinciodine.

\section{Results}

Only two ciliate species, Entodinium caudatum and Entodinium simplex were found in the first week after birth in a single lamb (14.2\%). In the second week, ciliates were detected in five animals $(71.1 \%)$. In the first lamb, only one species, Entodinium dubardi, was found, in the second lamb only Entodinium longinucleatum occurred. In the third animal 2 species, Entodinium caudatum and Entodinium simplex were encountered. In the fourth lamb, 4 species were identified, namely Entodinium bursa, $E$. longinucleatum, $E$. ovinum and $E$. simplex. Also in the fifth lamb, four species were found; Entodinium bursa, E. caudatum, E. dubardi and Polyplastron multivesiculatum. From the third week after birth, infusoria were detected in all seven lambs (100\%), however, the species distribution differed. The species Eremoplastron bovis and Enoploplastron triloricatum occurred. From the fifth week also Entodinium nanellum, E. dilobum, Diploplastron affine and Isotricha prostoma were identified. From the sixth week Entodinium minimum and $E$. lobosospinosum, from the eighth week Ophryoscolex tricoronatus and Dasytricha ruminantium enriched the rumen fauna of lambs.

The species Entodinium caudatum, E. dubardi, E. simplex and Polyplastron multivesiculatum were identified in all or nearly all lambs from the fifth week after birth, Isotricha prostoma occurred in majority of lambs as late as from eleventh week (Table 1).

In lambs aged two to three weeks, the numbers of ciliates per $1 \mathrm{ml}$ of rumen

Table 1

Ciliate species occurring in numbers of lambs aged 1 to 12 weeks

\begin{tabular}{|c|c|c|c|c|c|c|c|c|c|c|c|c|}
\hline Week Species & 1 & 2 & 3 & 4 & 5 & 6 & 7 & 8 & 9 & 10 & 11 & 12 \\
\hline $\begin{array}{l}\text { Entodinium } \\
\text { bursa } \\
\text { caudatum } \\
\text { dilobum } \\
\text { dubardi } \\
\text { longinucleatum } \\
\text { nanellum } \\
\text { ovinum } \\
\text { simplex } \\
\text { Eremoplastron } \\
\text { bovis } \\
\text { Diploplastron } \\
\text { affine } \\
\text { Polyplastron } \\
\text { multivesiculatum } \\
\text { Enoploplastron } \\
\text { triloricatum } \\
\text { Ophryoscolex } \\
\text { tricoronatus } \\
\text { Isotricha } \\
\text { prostoma } \\
\text { intestinalis } \\
\text { Dasytricha } \\
\text { ruminantium }\end{array}$ & $\begin{array}{l}- \\
- \\
- \\
- \\
- \\
- \\
-\end{array}$ & $\begin{array}{l}- \\
1 \\
- \\
- \\
- \\
-\end{array}$ & $\begin{array}{l}1 \\
4 \\
3 \\
2 \\
- \\
5\end{array}$ & $\begin{array}{r}4 \\
4 \\
-5 \\
3 \\
- \\
5\end{array}$ & $\begin{array}{l}4 \\
6 \\
1 \\
6 \\
3 \\
2 \\
1 \\
7\end{array}$ & $\begin{array}{l}3 \\
7 \\
-7 \\
3 \\
3 \\
2 \\
1 \\
6\end{array}$ & $\begin{array}{r}1 \\
6 \\
1 \\
7 \\
2 \\
4 \\
7\end{array}$ & $\begin{array}{l}4 \\
6 \\
1 \\
7 \\
4 \\
3 \\
1 \\
7\end{array}$ & $\begin{array}{r}6 \\
6 \\
1 \\
7 \\
2 \\
- \\
7\end{array}$ & $\begin{array}{l}6 \\
7 \\
1 \\
6 \\
3 \\
1 \\
7\end{array}$ & $\begin{array}{l}1 \\
7 \\
1 \\
6 \\
6 \\
1 \\
7\end{array}$ & $\begin{array}{c}- \\
6 \\
2 \\
7 \\
1 \\
4 \\
\overline{7}\end{array}$ \\
\hline
\end{tabular}


fluid oscillated around 7 thousands, increased until the fourth week to about 60 thousand and in the following weeks reached 300 thousand to 1 million individuals. In the development of ruminal microfauna, the most numerous was the genus Entodinium (Table 2). In the sixth week after birth, the largest numbers were those of the genus Diploplastron (38 thousand $/ \mathrm{ml}$ ). The genus Dasytricha showed higher numbers in the 9th (11 thousand/ml) and 12th (14 thousand/ml) week after birth.

In dams, the following numbers (in thousands) per $1 \mathrm{ml}$ rumen fluid were found: a total of $274.4 \pm 100.8$ ciliates. Of this number, the genus Entodinium comprised $247.6 \pm 97.0$, Eudiplodinium maggii $0.1 \pm 0.2$, Diploplastron affine $1.3 \pm 0.2$, Enoploplastron triloricatum $2.3 \pm 1.3$, Polyplastron multivesiculatum $0.1 \pm 0.2$, Ostracodinium gracile $0.4 \pm 0.6$, Ophryoscolex tricoronatus $0.2 \pm 0.4$, Isotricha $1.0 \pm 1.0$ and Dasytricha ruminantium $21.4 \pm 17.6$ individuals. Numbers of ciliates similar to their dams $\left(10^{5} \times 2.7 \mathrm{ml}^{-1}\right)$ were not encountered before week five in lambs.

The species Entodinium bursa, E. caudatum, E. dubardi, E. longinucleatum and Polyplastron multivesiculatum detected in lambs in the second week after birth, were also found in their mothers. Other ciliate species detected in dams in the second week after delivery were encountered in their lambs at various intervals as follows: Diploplastron affine in week 5, Enoploplastron triloricatum in week 3, Ophryoscolex tricoronatus in week 8, Isotricha prostoma in week 5 and Dasytricha ruminantium in week 8 after birth of lambs. The species Eudiplodinium maggii and Ostracodinium gracile found in dams were not detected in lambs at all.

\section{Discussion}

Occurrence of ciliates in young ruminants has repeatedly been studied. In calves, first ciliates were detected in the 12th to 15th day after birth (Belen kij 1953). In calves living in contact with their dams, first ciliates occurred in week 13 while in those separated from their mothers no ciliates were found before week 19 after birth (Crha and Holub 1978). Borhami et al. (1967) detected ciliates in calves as late as at 4 months of age whereas Hungate (1966) reported their occurrence within the first week of life. The genera Entodinium and Diplodinium emerged as first (Oxford 1955), according to Bryant et al. (1958) the genus Entodinium was present before the genus Diplodinium that in turn occurred earlier that the family Isotrichidae. Crha and Holub (1978) detected in calves first the species Entodinium simplex and E. bursa, followed by Epidinium ecaudatum and Isotricha prostoma.

First occurrence of ciliates in lambs was described by Fonty et al. (1986) in the second and third weeks after birth. According to these authors, first the genus Entodinium occurs from day 10 onwards. This finding corresponds with our data. From day 20, these authors began to find the genus Polyplastron that was also detected in our study in the same period, and further, the genus Eudiplodinium and Epidinium that we did not encounter. On the other hand, we detected the species Isotricha prostoma as soon as in the fifth week whereas Fonty et al. (1986) reported its occurrence in the eighth week after birth of lambs. It is remarkable that in the present study several ciliate species occurring in mothers were not detected in their lambs despite their mutual contact. 


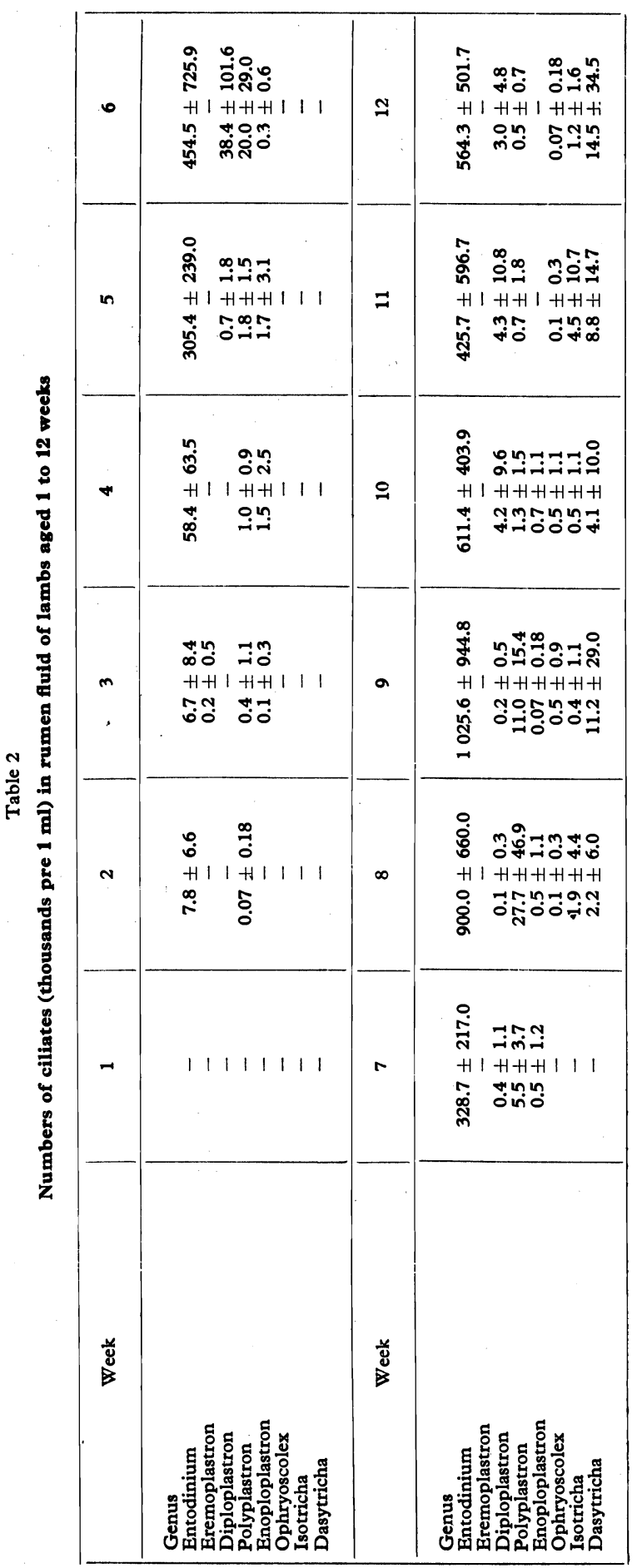




\section{Bachoroví nálevníci v ontogeneze jehňat}

Byl studován vývoj mikrofauny jehňat do tři měsíců po jejich narození. $\mathrm{V} 1$. týdnu po narození jehňat byli u nich zjištěni zástupci rodu Entodinium, v 2. týdnu Polyplastron multivesiculatum, ve 3. týdnu Eremoplastron bovis a Enoploplastron triloricatum, v 5. týdnu Diploplastron affine a Isotricha prostoma a v 8. týdnu Ophryoscolex tricoronatus a Dasytricha ruminantium. Prưměrný počet nálevnikủ ve 2. a 3. týdnu byl $7 \times 10^{3} \mathrm{ml}^{-1}$, ve 4 . týdnu $6 \times 10^{3} \mathrm{ml}^{-1} \mathrm{a} \mathrm{v}$ dalších týdnech se pohyboval od $3 \times 10^{3}$ do $1 \times 10^{4} \mathrm{ml}^{-1}$ bachorové tekutiny.

\section{Инфузории рубца в онтогенезе ягнят}

Проводили исследования развития микрофауны ягнят до трех месяцев после их рождения. На первой неделе после рождения были выявлены представители рода Entodinium, на второй неделе - Polyplastron multivesiculatum, на третьей неделе - Eremoplastron bovis и Enoploplastron triloricatum, на пятой неделе - Diploplastron affine и Isotricha prostoma и на восьмой неделе - Ophryoscolex tricoronatus и Dasytricha ruminantium. Среднее число инфузорий В течение 2 и 3 недель достигало $7 \times 10^{3}$ мл-1, 4 недели - $6 \times 10^{3}$ мл-1 и в течение последующих недель - $3 \times 10^{3}-1 \times 10^{4}$ мл-1 жидкости рубца

\section{References}

BELEŇKIJ, K. G.: Infuzorizacija těljat. Veterinarija (Moskva), 30, 1953: 25-35

BORHAMI, B. E. A. - EL SHAZLY, K.-ABOU AKKADA, A. R. -AHMED, I. A.: Effect of Early Establishment of Ciliate Protozoa in the Rumen on Microbial Activity and Growth of Early Weaned Buffalo Calves. J. Dairy Sci., 50, 1967: 1654-1659

BRYANT, M. P.-SMALL, N. - BOUMA, C.-ROBINSON, I.: - Studies on the composition of the ruminal flora and fauna of young calves. J. Dairy Sci., 41, 1958: 1747-1767

CRHA, J.-HOLUB, A.: Rumen Fauna in Calves Raised in Isolation from the Dams. Acta vet. Brno, 47, 1978: 127-135

DOGIEL, V. A.: Monographie der Familie Ophryoscolecidae. Arch. Protistenkde, 59, 1927: $1-288$

FONTY, G.-JOUANY, J. P.-SÉNAUD, J.-GOUET, Ph.-GRAIN, J.: The evolution of microflora, microfauna and digestion in the rumen of lambs from birth to 4 months. Can. $J$. anim. Sci, 64, 1984: 165-166

FONTY, G-JOUANY, J. P. - GOUET, Ph. - SÉNAUD, J.: Influence du régime alimentaire et de la méthode d'élevage sur l'implantation des bactéries cellulolytiques et des protozoaires ciliés dans le rumen de l'agneau. Reprod. Nutr. Dévelop., 26, 1986: 283-284

FONTY, G.-GOUET, Ph.-JOUANY, J. P.-SÉNAUD, J.: Rôle de la microflore sur la cinétique d'apparition des protozoaires ciliés dans le rumen de l'agneau. Reprod. Nutr. Dévelop., 26, 1986: 285-286

HUNGATE, R. E.: The Rumen and Its Microbes. Academic Press, New York, 1966: pp. $91-147$

KOFOID, C. A.-MAC LENNAN, R. F.: Ciliates from Bos indicus L. Univ. Calif. Publ. Zool., 33, 1930: 471-544; 37, 1932: 53-152; 39, 1933: 1-34

LATTEUR, B: Contribution a la systematique de la famille des Ophryoscolecidae Stein. Ann. Soc. roy. zool. Belg., 96, 1966: 117-144

OXFORD, A. E.: The rumen ciliate Protozoa. Their chemical composition, metabolism, requirements for maitenance and culture, and physiological significance for the host. Exp. Parasit., 4, 1955: 569-605 